
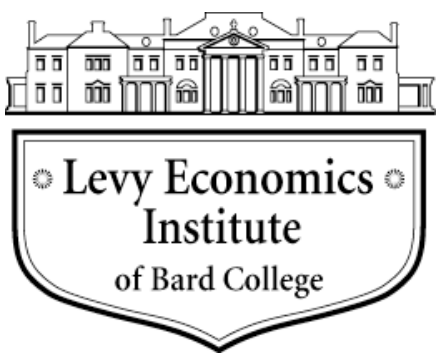

Working Paper No. 824

\title{
Building the Entrepreneurial State: A New Framework for Envisioning and Evaluating a Mission-oriented Public Sector
}

\author{
by
}

\author{
Mariana Mazzucato* \\ University of Sussex
}

January 2015

\footnotetext{
- RM Phillips Professor in the Economics of Innovation, SPRU, University of Sussex, www.marianamazzucato.com; M.Mazzucato@sussex.ac.uk
}

This paper was prepared for the project "Financing Innovation: An Application of a Keynes-SchumpeterMinsky Synthesis," funded in part by the Institute for New Economic Thinking, INET grant no. IN012-00036, administered through the Levy Economics Institute of Bard College; Mariana Mazzucato (Science Policy Research Unit, University of Sussex) and L. Randall Wray (Levy Institute) are the project's co-principal investigators. The author thanks INET, SPRU, and the Levy Institute for support of this research.

The Levy Economics Institute Working Paper Collection presents research in progress by Levy Institute scholars and conference participants. The purpose of the series is to disseminate ideas to and elicit comments from academics and professionals.

Levy Economics Institute of Bard College, founded in 1986, is a nonprofit, nonpartisan, independently funded research organization devoted to public service. Through scholarship and economic research it generates viable, effective public policy responses to important economic problems that profoundly affect the quality of life in the United States and abroad.

Levy Economics Institute

$$
\text { P.O. Box } 5000
$$

Annandale-on-Hudson, NY 12504-5000

http://www.levyinstitute.org

Copyright (C) Levy Economics Institute 2015 All rights reserved 


\begin{abstract}
Today, countries around the world are seeking "smart" innovation-led growth, and hoping that this growth is also more "inclusive" and "sustainable" than in the past. This paper argues that such a feat requires rethinking the role of government and public policy in the economy-not only funding the "rate" of innovation, but also envisioning its "direction." It requires a new justification of government intervention that goes beyond the usual one of "fixing market failures." It also requires the shaping and creating of markets. And to render such growth more "inclusive," it requires attention to the ensuing distribution of "risks and rewards."
\end{abstract}

To approach the innovation challenge of the future, we must redirect the discussion, away from the worry about "picking winners" and "crowding out" toward four key questions for the future:

1. Directions: how can public policy be understood in terms of setting the direction and route of change; that is, shaping and creating markets rather than just fixing them? What can be learned from the ways in which directions were set in the past, and how can we stimulate more democratic debate about such directionality?

2. Evaluation: how can an alternative conceptualization of the role of the public sector in the economy (alternative to MFT) translate into new indicators and assessment tools for evaluating public policies beyond the microeconomic cost/benefit analysis? How does this alter the crowding in/out narrative?

3. Organizational change: how should public organizations be structured so they accommodate the risk-taking and explorative capacity, and the capabilities needed to envision and manage contemporary challenges?

4. Risks and Rewards: how can this alternative conceptualization be implemented so that it frames investment tools so that they not only socialize risk, but also have the potential to socialize the rewards that enable "smart growth" to also be "inclusive growth"?

Keywords: Finance; Industrial Policy; Mission-oriented Innovation

JEL Classifications: L1, L5, 038, 025 


\section{INTRODUCTION}

The important thing for Government is not to do things which individuals are doing already, and to do them a little better or a little worse; but to do those things which at present are not done at all (John M. Keynes, The End of Laissez Faire, 1926).

Today, countries around the world are seeking "smart" innovation-led growth, and hoping that this growth is also more "inclusive" and "sustainable" than in the past (European Commission, 2010). This paper argues that such a feat requires rethinking the role of government and public policy in the economy - funding not only the "rate" of innovation, but also envisioning its “direction'." It requires a new justification of government intervention that goes beyond the usual one of "fixing market failures." It requires the shaping and creating of markets. And to render such growth more "inclusive," it requires attention to the ensuing distribution of "risks and rewards."

\section{The Context}

Modern capitalism faces a number of great societal challenges, including climate change, youth unemployment, obesity, ageing, and rising inequality. These challenges have created a new agenda for innovation and growth policy that require policymakers to "think big" about what kind of technologies and socioeconomic policies can fulfill visionary ambitions to make growth more smart, inclusive and sustainable (see, for instance, the "Europe 2020" strategy, in European Commission, 2010).

Although such challenges are not strictly technological (as they also require behavioral and systemic changes), they have much to learn from those "mission-oriented" feats (Foray et al., 2012) that led to putting a man on the moon, or to those that led to the emergence of new general-purpose technologies, ranging from the Internet to biotechnology, and nanotechnology. Achieving such missions required companies that were willing and able to invest in long-run areas, and a confident "entrepreneurial state" willing and able to take on the early, capitalintensive, high-risk areas which the private sector tends to fear (Mazzucato, 2013a). A state is entrepreneurial when it is able and willing to invest in areas of extreme uncertainty, courageously envisioning the direction of change across public agencies and departments. An entrepreneurial state must welcome, rather than fear, the high risk and uncertainty across the 
entire innovation chain (from basic research to commercialization) and the experimentation processes required for organizational learning along the way (Hirschman, 1967; Rodrik, 2013). Most importantly, an entrepreneurial state must "think big" (Mazzucato, 2013a).

Today, it is increasingly difficult for states to think big. We live in an era in which the role of government is being limited to simply "facilitating" and "de-risking" the private sector; fixing market failures, rather than having a direct role in creating and shaping markets, determining the direction of change, with the adequate budgets and governmental structures to do so. Indeed, when government agencies step out of this "facilitating" role, they are immediately accused of "crowding out" or "picking winners."

The difficulties that governments have in thinking big stem from various forces. Since the 1970s, the idea of government as a simple "regulator" and "administrator" has become prevalent, alongside attempts to downsize the state (Judt, 2011). And the emphasis since the Global Financial Crisis on cutting public debt (even though it was private debt that caused the crisis) has inevitably affected the budgets of the very state agencies that have been responsible for creating both the horizontal and vertical types of investments needed to catalyze the technological revolutions of the past. In the US, "sequestration" has put close to one-third of the US public R\&D budget ( $\$ 130$ billion per year) at risk (LaMonica, 2013). In Europe, the "fiscal compact" (which requires member states to have fiscal deficits that are only 3 percent of their GDP) is putting pressure on counties to cut spending on areas like education and R\&D. Spaina critical case — has cut publicly funded R\&D by 40 percent since 2009 (Buck, 2013). In the UK, while the government has "ring-fenced" the science budget, in real (inflation-adjusted) terms, this has meant a 15-percent cut (Weir, 2014). Meanwhile, the opposite trend is occurring in countries that continue to grow. Germany has increased its education, research and science budget by the same amount ( $€ 10$ billion per year) since 2009 , raising it to almost 10 percent of its GDP (FMER, 2013); while China has made increases in this area of 170 percent over the last five years.

Nevertheless, finding a way for government to think big is not just about throwing public money at different activities. It requires a new economic framework that can justify the role of the public sector in "directing" change, forming the right institutional structures that can foster and adapt to change in a dynamic way. It requires a framework that justifies the catalytic role of government, its ability to transform landscapes, and create and shape markets - not just fix 
them. It requires new indicators through which public investments can be evaluated, which captures the "transformational" catalytic impact that Keynes (1926) suggested should be the objective (“doing those things which at present are not done at all”). It requires different insights on the organization of government, and on the distribution of risks and rewards that emerge from the collective effort toward "smart" innovation-led growth.

\section{BEYOND MARKET FAILURES}

The road to the free market was opened and kept open by an enormous increase in continuous, centrally organized and controlled interventionism (Karl Polanyi, The Great Transformation, 1944).

Market failure theory (MFT) justifies public intervention in the economy only if it is geared toward fixing situations in which markets fail to efficiently allocate resources (Arrow, 1951). The market failure approach suggests that governments intervene to "fix" markets by investing in areas with "public goods" characteristics (such as basic research, or drugs with little market potential) and by devising market mechanisms to internalize external costs (such as pollution) or external benefits (such as herd immunity). Figure 1 depicts five key sources of market failures; that is, factors or behaviors that result in costs or benefits that are not reflected in the price system.

Within the mainstream framework, market failure is a necessary but not sufficient condition for governmental intervention (Wolf, 1988). The sufficiency results from an assessment that the gains from the intervention outweigh the associated costs due to “governmental failures" (Tullock et al., 2002)—such as capture by private interests (nepotism, cronyism, corruption, and rent-seeking) (Krueger, 1974), misallocation of resources (for example, "picking losers") (Falck et al., 2011), or undue competition with private initiatives (“crowding out") (Friedman, 1979). Thus, there is a trade-off between two inefficient outcomes; one is generated by free markets (market failure) and the other by governmental intervention (government failure). The solutions advocated by neo-Keynesians focus on correcting failures such as imperfect information (Stiglitz and Weiss, 1981). Solutions advocated by public choice scholars (Buchanan, 2003) focus on leaving resource allocation to markets (which may be able to correct their failures on their own). 
Figure 1 Types/Sources of Market Failures

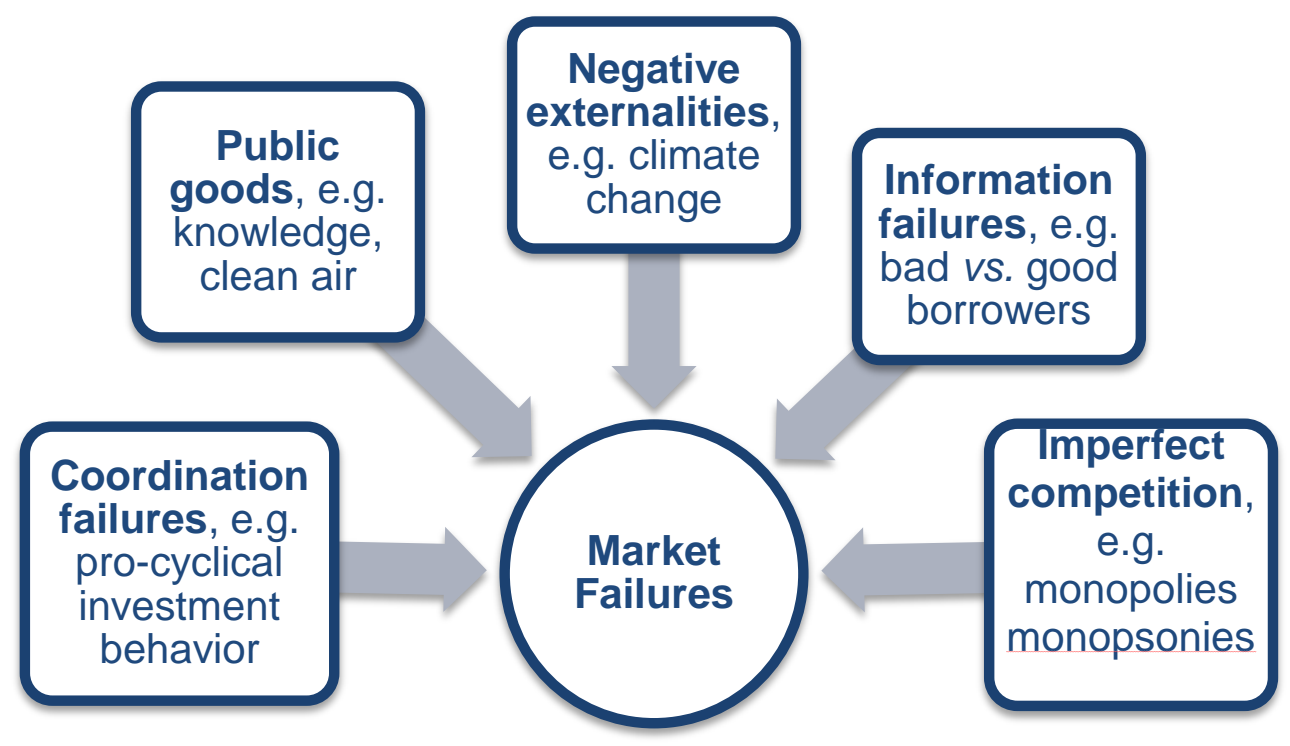

Source: Based on typology of market failures developed by Mazzucato and Penna (2014).

While market failure theory provides interesting insights, it is at best useful for describing a steady state scenario in which public policy aims to put patches on existing trajectories provided by markets. It is less useful when policy is needed to dynamically create and shape new markets_- "transformation." This means it is problematic for addressing innovation and societal challenges because it cannot explain the kinds of transformative, catalytic, mission-oriented public investments that in the past created new technologies and sectors which did not exist before (the Internet, nanotech, biotech, cleantech), and which the private sector feared. It was such mission-oriented investments that coordinated public and private initiatives, built new networks, and drove the entire techno-economic process, which resulted in the creation of new markets.

There are four key limitations in the MFT framework, which continues to guide policymaking today regarding its insights on the ability of the state to set the direction of change, to form indicators through which to evaluate its transformational impact, to set up organizations in the public sector that are willing and able to welcome rather than fear failure, and the ability to earn some return from the upside to fund the many inevitable failures that are part and parcel of the innovation process. These limitations are listed below: 


\section{Directionality: Envisioning and "Picking" Strategically}

Policies that aim to correct markets assume that once the sources of the failure have been addressed, market forces will efficiently direct the economy to a path of growth and development. Yet, markets are "blind" (Nelson and Winter, 1982; Dosi, 1982) and the direction of change provided by markets often represents suboptimal outcomes from a societal point of view. This is why, in addressing societal challenges, states have had to lead the process and provide the direction toward new "techno-economic paradigms" (Perez, 2002), which do not come about spontaneously out of market forces. In the mass production revolution and the IT revolution, governments made direct "mission-oriented" investments in the technologies that enabled these revolutions to emerge, and formulated bold policies that allowed them to be fully deployed throughout the economy (Mowery, 2010; Block and Keller, 2011). As shown in "The Entrepreneurial State: Debunking the Public vs. Private Myth in Risk and Innovation" (Mazzucato, 2013a), every technology that makes the iPhone "smart" (Internet, GPS, touchscreen display, and SIRI) was publicly funded directly (Figure 2 below), and even the deployment of most "general purpose technologies" (from electricity to IT) was an outcome of public policy (Perez, 2002). The examples go beyond the usual "military industrial complex" investments in the Department of Defense (Weiss, 2014). The National Institutes of Health (NIH) have spent on the pharm-biotech knowledge base, which Angell (2004) claims has been behind the most radical new drugs. Between 1936 and 2011, the NIH spent close to $\$ 800$ billion on the pharma-biotech knowledge base (\$31.9 billion in 2012), with the work of Angell (1984) showing that this funding has been behind the most radical advances in medicine (new molecular entities with priority rating).

Furthermore, in the IT revolution, and even in the emerging clean-tech revolution, government not only funded the actual technologies (such as mainframes, the Internet, wind and solar power, and fuel cells), but also created a network of decentralized public and private actors (a "developmental network state") (Block and Keller, 2011), provided early-stage funding to companies that risk-averse private finance would not, and devised special tax credits that favored some activities more than others (Mazzucato, 2013a; 2013b). These facts seem to point to a different analytical problem facing policy makers: not whether the right role is one of intervention or standing back, but understanding how particular "directions" and routes can be 
chosen, and determining how to mobilize and manage activities that can lead to the achievement of dynamic social and technological challenges.

Figure 2 State Investments Funded all of the Key Technologies Behind the iPhone

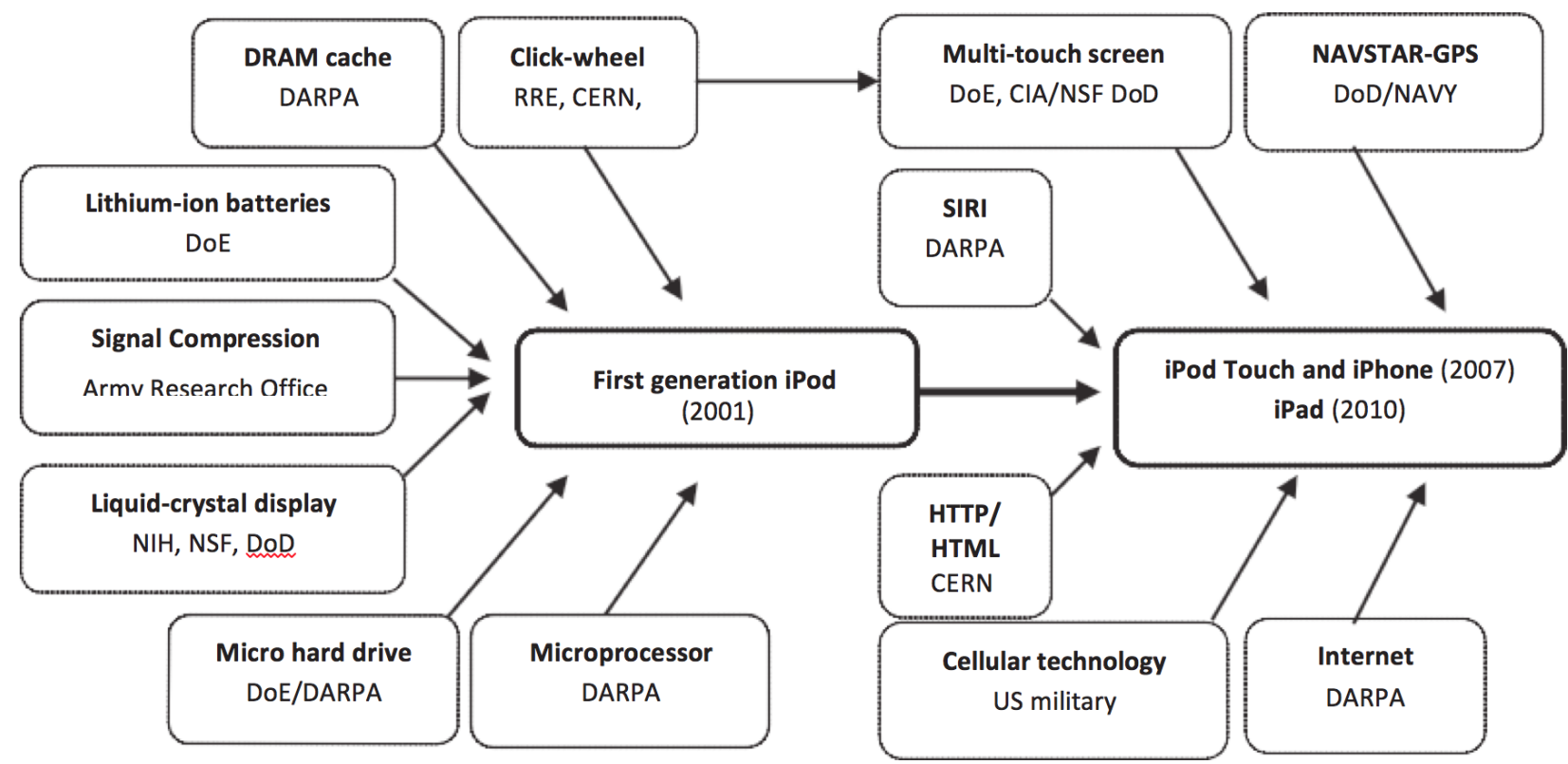

Source: Mazzucato (2013a, p. 109).

\section{Evaluation: Static vs. Dynamic Metrics}

MFT has developed concrete indicators and methods to evaluate government investments, which stem from the framework itself, usually through a cost-benefit analysis that estimates whether the benefits of public intervention compensate for the costs associated with both the market failure and the implementation of the policy (including "governmental failures"). However, there is a mismatch between the intrinsically dynamic character of economic development and the static tools used to evaluate policy. The diagnostic tools and evaluation approach based on MFT involve identifying the sources of market failure and targeting policy interventions on their correction. This entails ex-ante considerations about administrative and fiscal requirements and the political-economic consequences of intervention. Such an exercise usually consists of the following steps:

- An ex-ante cost-benefit analysis that weighs up the costs of the failure, the (private and social) benefits from addressing it, and the costs and risks of government failure. 
- An ex-ante identification of sources of market failures and of second-best policy tools to address them.

- An ex-ante diagnostic of the best principal-agent structure that avoids governmental capture by private interests (insulation/autonomy) and that forces private agents to do what the principal (government) wants.

- An ex-post evaluation of the outcomes of the intervention vis-à-vis the ex-ante quantifiable prediction of the likely outcomes of the intervention.

Yet this is a limited toolbox for evaluating public policies and investments that aim to address societal challenges, because doing so represents a static exercise of evaluation of an intrinsically dynamic process. By not allowing for the possibility that government can transform and create new landscapes that did not exist before, the ability to measure such impact has been affected, with economists often resorting to an analysis of the public sector as an inefficient private one (Mazzucato, 2013a). This is evident not only in the area of innovation, but also for public services. This then leads to accusations of government "crowding out" businesses, which implies that those areas that government moves into could have been areas for business investment. Such accusations are at best defended through a "crowding in" argument, which rests on showing how government investments create a larger pie of national output that can be shared (the savings) between private and public investors. However, this defense does not capture the fact that the goal of public investments should be to not only "kickstart" the economy but to choose directions that "do those things which at present are not done at all" (Keynes, 1926). By not having indicators for such transformative action, the toolbox affects the government's ability to know when it is simply operating in existing spaces or making new things happen that would not have happened anyway (its "additionality"). This often leads to investments that are too narrow or directed within the confines of the boundaries set by business practices of the prevailing techno-economic paradigm (Abraham, 2010).

\section{Organization: Learning, Experimentation and Self-discovery}

If brought to its extreme, as advocated by critics from Public Choice, MFT calls for the state to intervene as little as possible in the economy, in a way that minimizes the risk of "government failure" (e.g., "crowding out," cronyism and corruption). This view requires a structure that 
insulates the public sector from the private sector (to avoid issues such as agency capture) and has resulted in a trend of "outsourcing" that often rids government of the knowledge capacities and capabilities (for example, around IT) that are necessary for managing change. Studies have examined the influence of outsourcing on the ability of public institutions to attract top-level talent with the relevant knowledge and skills to manage transformative mission-oriented policies (Kakabadse and Kakabadse, 2002). Without such talent and expertise it will be difficult for the state to coordinate and provide direction to private actors when formulating and implementing policies that address societal challenges. Indeed, there seems to be a self-fulfilling prophecy whereby the less "big thinking" occurs in government, the less talent/expertise the public sector is able to attract, the less well it performs, and the less "big thinking" it is allowed to do. In order to promote transformation of the economy, by shaping and creating technologies, sectors, and markets, the state must organize itself so that it has the "intelligence" (policy capacity) to think big and formulate bold policies. This does not mean it will always succeed; indeed the underlying uncertainty in the innovation process means that the state will often fail (Nelson and Winter, 1982; Hirschman, 1967). If the emphasis is on the process of policy making (Rodrik, 2013) that can allow the public sector to envision and manage transformational change, then understanding the appropriate structures of public organizations and their "absorptive capacity" (Cohen and Levinthal, 1990) is essential.

\section{Risks and Rewards: Toward Symbiotic Private-public Partnerships}

MFT says little about cases in which the state is the lead investor and risk taker in capitalist economies through "mission-oriented" investments and policies (Foray et al., 2012). Having a vision of which way to drive an economy requires direct and indirect investment in particular areas - not just "creating the conditions" for change. This requires crucial choices to be made, the fruits of which will create some winners, but also many losers. Figure 3 below shows how much public money has been spent on early stage seed financing through the US Small Business Innovation Research program. Indeed, precisely because venture capital has become increasingly short-termist, with emphasis on an exit in three years (while innovation takes 1520 years!), such funding has become increasingly important, as have guaranteed loans for innovative high-risk projects. For example, the Obama administration in the US recently provided a direct $\$ 500$ million loan to two green-tech companies, Solyndra and Tesla Motors. 
While the latter is often glorified as a success story, the former failed miserably and became the latest example, used widely by both economists and, the more popular treatment in the media, of government being unable to "pick winners." Indeed, the taxpayer picked up the bill (Wood, 2012), and complained. This highlights the need to build a theoretical framework that can help the public sector understand (a) its "portfolio" choices (Rodrik, 2013) and (b) how to socialize not only the risks of those investments but also the rewards. Is it right that the taxpayer shouldered the Solyndra loss, yet made nothing from the Tesla profits?

Figure 3 Early-stage and Seed Funding Awards, SBIR and Venture Capital



Source: Adapted from Block and Keller (2012).

The question comes down to whether, in an MFT framework, the government deserves to retain a direct share of the profits generated from the growth that it fosters. Or put another way, are taxes currently bringing back enough return to government budgets to fund high-risk investments that will probably fail? It is well known that companies that benefit greatly from government investments have been successful in avoiding tax: Google, whose algorithm was funded by the NSF, has been criticized for such avoidance, as have Apple and Amazon and a host of "new economy" companies. Even if they were not dodging tax, tax rates, such as those on capital gains, have been falling due to the narrative that it is a narrow set of agents who are 
the real innovators and risk takers (Lazonick and Mazzucato, 2013) ${ }^{1}$. We return to this crucial issue below.

\section{WHO IS FUNDING THE GREEN ECONOMY?}

A key element to get an energy breakthrough is more basic research. And that requires the government to take the lead. Only when that research is pointing towards a product then we can expect the private sector to kick in (Bill Gates) ${ }^{2}$.

Public finance played the lead role in IT, biotech and nanotech, and today we are witnessing a similarly active role of state funding for innovation in the emerging green economy. Looking at worldwide investments aimed at the global challenge of limiting carbon emissions (such as investments in renewable energies), the figures are striking (see Figure 4). In 2012, the share of public "development finance institutions" (also known as "development banks" or "state investment banks") in the "climate finance landscape" was 34 percent (the highest share of any single type of actor), compared to 29 percent for project developers (including public utilities), 19 percent for corporate actors, 9 percent for households, 6 percent for all types of private financial institutions and 3 percent for executive governments (investments from governmental budgets) ${ }^{3}$ (Climate Policy Initiative, 2013).

\footnotetext{
${ }^{1}$ It was the National Venture Capital Association that in the late 1970s lobbied for capital gains tax to fall from $39.6 \%$ to $20 \%$ in 5 years (Lazonick and Mazzucato, 2013). Warren Buffett (2011) has admitted that such tax changes did not affect investment, only inequality.

${ }^{2}$ Source: American Energy Industry Council, http://www.youtube.com/watch?v=x54bVuduggU (accessed 1 June, 2014).

${ }^{3}$ The figure for executive governments does not consider their US\$37 billion participation in areas such as public utilities, which the Climate Policy Initiative has classified as private investments.
} 
Figure 4 Finance for Climate Change Adaptation and Mitigation Projects by Source (2012)

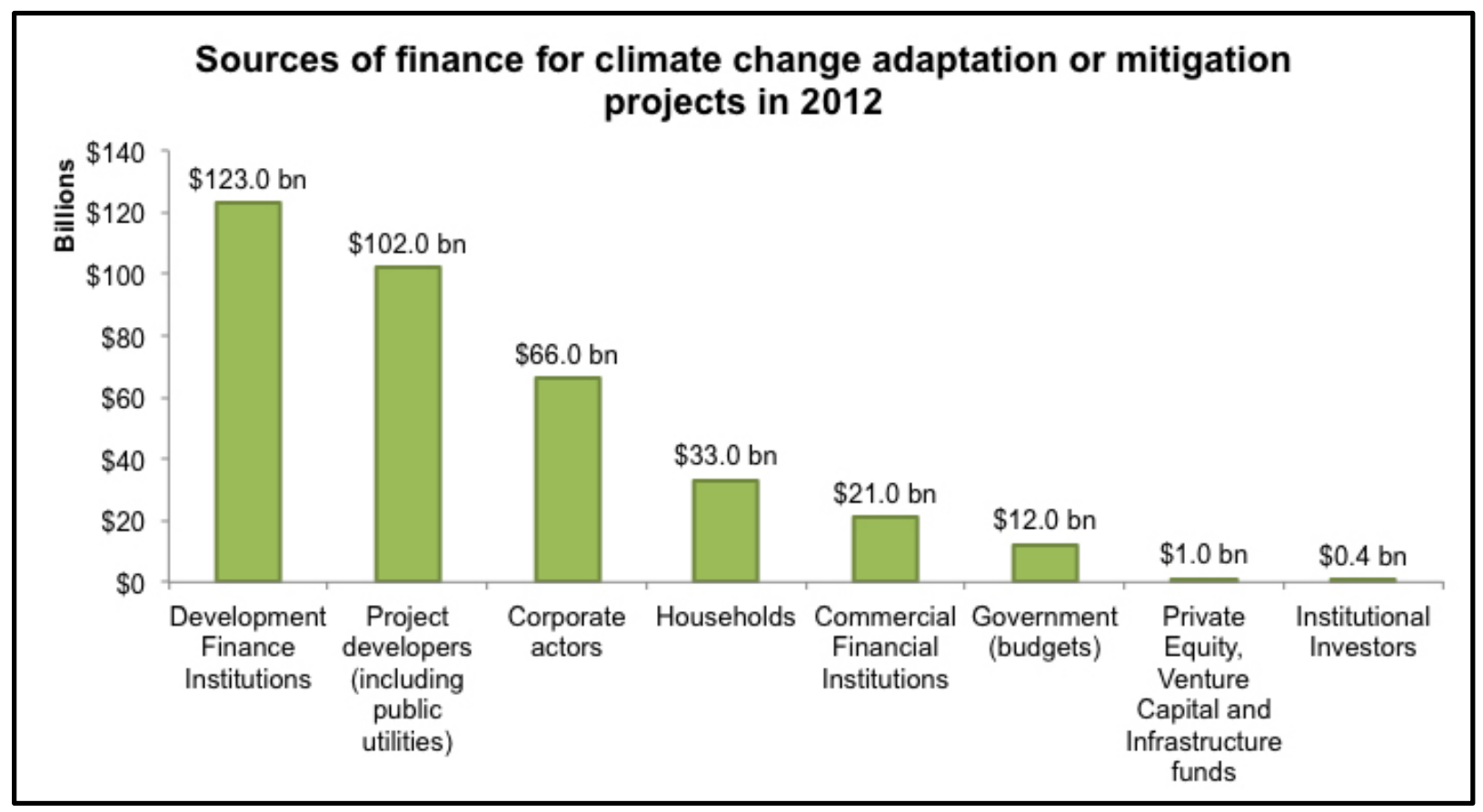

Source: Based on data from Climate Policy Initiative (2013).

Indeed, in recent decades, the traditional roles of state investment banks (SIBs) counter-cyclical lending and promoting of capital development of the economy-have been supplemented by two new roles: support for innovative enterprises ("venture capitalist" role) and promotion of investments that contribute to addressing societal challenges (a "missionoriented" or "challenge-led" role) (Mazzucato and Penna, 2014). The distinctive ethos of SIBs was summarized in a recent report of the Global Wind Energy Council (GWEC) as follows:

The main factor that distinguishes development banks from private sector lending institutions is the ability of development banks to take more risk associated with political, economic and locational aspects. Further, since they are not required to pay dividends to private stakeholders, the development banks take higher risks than commercial banks to meet various national or international "public good" objectives. Additionally, long-term finance from the private sector for more than a ten year maturity period is not available (Fried et al., 2012, p. 6).

Thus, the roles and scope of action of SIBs are more diverse and complex than simply financing projects. SIBs can set conditions for access to their capital, in an effort to maximize economic or social value to their home country. More importantly, through their venture capitalist and mission-oriented roles (which are often intertwined), SIBs provide a clear direction to economic development: they are suppliers of the "visionary capital" (Mazzucato 
and Penna, 2014) that allows for the qualitative transformation of "techno-economic paradigms" (Perez, 2002); this is something that markets alone are not able to do.

The issue of directionality of technical innovation is crucial (Stirling, 2009).

Technological development has both quantitative characteristics (such as the amount of cost savings, productivity improvements, etc.) and qualitative aspects (which can be captured by issues such as the kind of technology and its purpose - in other words, its direction). However, the latter aspects are often neglected, leading to situations in which public investments are directed toward questionable areas (including an over-emphasis on "commercialization" as argued recently by Weiss, 2014) or in the wrong direction altogether. Shale gas, which was fully funded by the US government (Shellenberger et al., 2012) is a case in point, considering the negative impact that the technology (fracking) required to produce it has on natural environments. Therefore, public investments to address societal challenges must give particular consideration to the types of vision and directionality they embody. It is also important to consider the involvement of civil society in the debate about such "directions" (Schot and Geels, 2007).

\section{SOCIALIZING BOTH RISKS AND REWARDS}

Instead of asking: what benefits [has] this project yielded, it would almost be more pertinent to ask: how many conflicts has it brought in its wake? How many crises has it occasioned and passed through? And these conflicts and crises should appear both on the benefit and the cost side, or sometimes on onesometimes on the other, depending on the outcome (which cannot be known with precision for a long time, if ever) (Alfred O. Hirschman). ${ }^{4}$

Returning to the fourth point made above on risks and rewards: mission-oriented public spending in IT, green, or health will generate some successes but also many failures. This is because innovation is a highly uncertain process; it takes a very long time to develop new technologies, and the effort often ends up in a dry hole. For every Tesla (companies that receive public funding, and become market darlings), there are many Solyndras (companies that receive public funding, and then go bankrupt). For every Internet (technologies funded by government with great success) there are many Concordes (projects funded by government that fail

\footnotetext{
${ }^{4}$ Cited in Adelman, J. (2013). Worldly philosopher: the odyssey of Albert O. Hirschman. Princeton: Princeton University Press, p. 313.
} 
commercially). Indeed, Solyndra's recent bankruptcy has been used to talk about government failure, not recogniZing that if government is to act like a venture capitalist, which it historically has, it will—like all VCs must — undergo many failures to reach some successes. However, what has not been thought through enough is the way to measure success and failure from a government standpoint, and also how to makes sure that, like private $\mathrm{VC}$ funds, the state can reap back some return from the successes in order to cover its losses, and the next round of investments: a revolving fund.

Economists argue that the state already earns back a return for its investments, indirectly via the taxation system. There are four arguments against this reasoning: (1) tax evasion (legal and illegal) is common and realistically will not disappear; (2) taxes, such as capital gains, have been falling over the last decades, precisely through a false narrative about who the wealth creators are; (3) global movements of capital mean that the particular country or region (e.g., the European Union) funding the innovation might not reap the benefits in terms of local job creation; and (4) while it is of course right to think that investments in the "basics," such as education, health and research, should not be thought about as earning a return, it is these directed investments at companies and particular technologies that pose a very different problem. If the state is being asked to make such investments (which it undoubtedly has been making and increasingly so, as financial markets have become even more speculative and shorttermist), it is necessary for it to cover its inevitable losses when those arise.

Where technological breakthroughs have occurred as a result of targeted state interventions for specific companies, there is potential for the state to reap some of the financial rewards over time, by retaining ownership of a small proportion of the intellectual property created. This is not to say the state should ever have exclusive license or hold a large enough proportion of the value of an innovation to deter a wider spread of its application (and this has never been the case) - the role of government is not to run commercial enterprises, but to spark innovation elsewhere. However, a government should explore whether it is possible to own some of the value it has created, which over time could generate significantly higher value and then be reinvested into growth-generating investments.

The state must do this not by adopting a conservative strategy that minimizes the risks of picking losing projects and maximizing the probability of picking winners, but by adopting a portfolio approach for its investments (Rodrik, 2013). This is key because attention to potential 
returns should not result in the public sector thinking like the private sector (profit maximizing, short-term focus on the bottom line). The public sector must attend to social purposes and outcomes, focusing on wide spillovers and benefits to the economy, not all of which are quantifiable in monetary terms. This is achieved through big thinking, setting up bold missionoriented policies to tackle societal challenges. There is no reason why ex-post returns cannot be considered if/once they appear, but quantifiable monetary outcomes should not be the scale of success. Realistically, if the innovation-funding cycle is to continue and not be susceptible to political whims, success from the few profitable projects must be able to cover the losses from the many inevitable, less successful (potentially very expensive) projects. What matters in this approach is not so much the matching between failures and fixes, but an institutional structure that ensures winning policies provide enough "rewards" to cover the losses, and that losses are used as learning cases to improve and renew future policies. Not many studies have considered public investments as part of a wider portfolio, and analyzed them as a whole. One exception is a 2001 study by the US National Research Council that evaluated fossil fuel and energy efficiency programs carried out by the Department of Energy from 1978 to 2000, which found that its portfolio of investments in the period (\$22.3 billion, in 1999 dollars) resulted in net positive benefits, basically due to the success of just three projects (National Research Council, 2001, cited in Rodrik, 2013). The point is that by adopting the portfolio approach to public investments in innovation, success from a few projects can then help cover the losses from many projects.

There are various ways to consider a direct return to the state for its investments in innovation. One is to make sure that loans and guarantees that are handed out by the state to business do not come without strings attached. Loans and grants could have conditions, such as "income-contingent loans," similar to those of student loans. If a company receives a loan or grant from the state, it should be required to pay back a portion if and when it makes profits above a certain threshold. This is not a complicated concept, of course, but it does run counter to some deep-seated assumptions. Currently, with budget deficits under so much pressure, it is no longer possible to ignore the issue.

Apart from income-contingent loans, there is the possibility of the state retaining equity in the companies that it supports. Indeed, this does occur in some countries, such as Israel (through the Yozma public venture capital fund) or in Finland (where SITRA, one of Finland's 
public funding agencies, retained equity in its early-stage investments in Nokia). To be sure, equity stakes are also retained by state investment banks, such as BNDES (through BNDESPar, or "BNDES Participations"), China Development Bank and KfW, which are two lead investors in the emerging green economy (Mazzucato and Penna, 2014). However, state equity in private companies is often feared in countries like the US and the UK (and other countries that have copied the Anglo-Saxon model) for fear that the next step is "communism"." Despite this fear, the most successful capitalist economies have had active states, making the risky investments that resulted in truly technological revolutions (Perez, 2002). We have been too quick to criticize public investments when things go wrong (for example, Concorde or Solyndra) and too slow to reward them when things go right (such as the Internet or Tesla).

\section{NEW INDICATORS TO CAPTURE THE CREATION AND SHAPING OF MARKETS: FROM CROWDING IN TO DYNAMIZING IN}

Practical men, who believe themselves to be quite exempt from any intellectual influence, are usually the slaves of some defunct economist. (...) I am sure that the power of vested interests is vastly exaggerated compared with the gradual encroachment of ideas (John M. Keynes, The General Theory of Employment Interest and Money, 1936).

The world is currently facing a conundrum. Too few places are active in innovation, and the few that are often get attacked for being too active: crowding out and picking winners. Critics claim that public investments, active industrial policies and other types of "governmental intervention" in the economy, while potentially justified in caseS of market failures, usually lead to worse outcomes due to government failure. Indeed, the common criticisms about crowding out (Friedman, 1979) or picking winners (Lisboa and Latif, 2013) - two types of "government failure"-derive directly from the limited (mainstream) theoretical perspective on what SIBs do (Mazzucato and Penna, 2014).

The crowding-out criticism can take two forms. On the one hand, public investment would prevent the development of a long-term capital market because it would displace (crowd out) private initiative. Managed long-term interest rates would crowd out credit that would otherwise be supplied by private agents in a free market, thereby inhibiting both the activity of commercial banks and the creation of a capital market. On the other hand, public investments would diminish the amount of savings available for private investment or lead to changes in 
exchange rates, both of which would lead to lower levelS of private investments. In 2010, for instance, the German development bank KfW was accused of crowding out "European sovereigns, supranationals and agencies issuing short-term debt" (EuroWeek, 11 March, 2011), because it was issuing "large amounts" of commercial papers. Theoretically, this facet of the crowding-out criticisms is associated with some mainstream (neo-Keynesian or new Classical) growth models that result in public investments crowding out private investments, particularly if governmental deficits are financed through debt (Friedman, 1979). However, the crowding out hypothesis is a matter of empirical investigation more than theoretical, particularly if the state is doing precisely what the private sector is not (Mazzucato and Penna, 2014).

A second common criticism attacks mission-oriented public investments that target particular technologies and sectors, in an attempt to pick winners. Critics argue that the state is poor at doing this because it lacks the capability, information and incentives that would make these attempts succeed (Hanson, 2004). In this view, politicians and bureaucrats are bad or biased managers who lack the discipline provided by markets. This criticism is summarized in an article from The Economist entitled "Picking winners, saving losers: the global revival of industrial policy," which concludes: "The present round of industrial policy will no doubt produce some modest successes - and a crop of whopping failures" (The Economist, August 5, 2010 , online). While the inability of the state to pick winners is often an a priori assumption of many analysts, very few studies have attempted to systematically evaluate attempts from the state to pick winners (from Concorde to Airbus) in order to set the record straight (Mazzucato and Penna, 2014).

Such criticisms are misplaced because they ignore both the essence of mission-oriented public investments and empirical evidence. Because they are derived from particular theories and models, it is necessary to develop a new theoretical framework that is able to explain and properly evaluate the transformative character of mission-oriented investments. These criticisms also ignore an uncomfortable fact: the increasing financialization of the real economy, in which private finance funds private finance (adding to the percentage of added value comprised of financial intermediation), and private companies sometimes spend more on gimmicks like share buybacks than on value-creation activities such as R\&D (Lazonick and Mazzucato, 2013). A new framework brings about new types of questions and new types criticisms. The point is not to defend the state and its public investments/activities per se but to make sure that the 
criticisms directed toward the state are not blind to dynamic transformative processes and outcomes, because they stem from a limited framework like market failure theory. This requires a new set of diagnostic and evaluation practices, with novel indicators that are able to capture the transformative dynamics of mission-oriented policies. Otherwise we have a self-fulfilling prophecy whereby a limited framework automatically judges as negative anything that steps outside its domain. For example, working with a portfolio means having both high-risk investments (of which most will fail) and low-risk investments (of which most will be steady earners), where the latter might include the support for more traditional firms and technologies that for whatever reason may need continued support in competitive markets. It is interesting to note that the state is often blamed for both: it should not be funding incumbents, and should not be risking tax payer money on the high-risk areas. This can lead to a paralytic state of doing nothing. It has also led to paralysis on the risk-reward relationship, whereby the failure to see government as lead risk taker and investor has made government too shy to act upon its rights (as agreed in the 1980 Bayh-Dole Act) to cap prices on drugs that are publicly funded or to exercise its option to buy shares of the companies to which the state provides early stage, high-risk guaranteed loans (e.g., as in the Tesla case, when the US government had an option, which it decided not to use, to buy 3 million shares when the share price was only $\$ 8$, compared to the $\$ 93$ when the loan was paid back. Currently, Tesla's shares fluctuate above \$200).

\section{CONCLUSION: A NEW FRAMEWORK REQUIRES NEW QUESTIONS}

The solutions derived from MFT (downsizing the state apparatus, promoting market-based mechanisms to counter market failures, insulating public agencies from the private sector, etc.) might hold for steady state situations, but not for the situations in which public policy is required for transformation, such as those witnessed through the technological and socioeconomic missions of the past. Such missions required an emphasis not on fixing market failures or minimizing government failures but on maximizing the transformative impact of policy that can shape and create markets.

Considering the need for government policy to "transform," be catalytic, and create and shape markets (not just fix them), helps reframe the key questions of economic policy from 
static ones that worry about crowding out and picking winners to more dynamic ones that are constructive in forming the types of public-private interactions that can create new innovation and industrial landscapes. In this perspective, it is key for government to not just pick different technologies or sectors, but to ask what it wants from those sectors. In the same way that putting a man on the moon required many sectors to interact, the "green" direction being debated today also requires all sectors to change. Green is not only about wind, solar, and biofuels, but also about new engines, new maintenance systems, and new ways of thinking about product obsolescence (Mazzucato and Perez, 2014). This is not about prescribing specific technologies, but providing directions of change which bottom-up solutions can then experiment around. As Stirling (2014) has recently put it:

The more demanding the innovation challenges like poverty, ill health or environmental damage, the greater becomes the importance of effective policy. This is not a question of "picking winners"- an uncertainty-shrouded dilemma which is anyhow equally shared between public, private and third sectors. Instead, it is about engaging widely across society, in order to build the most fruitful conditions for deciding what "winning" even means.

Government would benefit from adopting a portfolio approach to public investments in innovations, and nurturing the explorative, plural, and trial-and-error aspect of change. This requires thinking not only about technological change in a new way, but also organizational change - building the public agencies of the future with creative, adaptive and explorative capacity.

In sum, this paper has argued that to approach the innovation challenges of the future, we must redirect the discussion, away from the worry about "picking winners" and "crowding out" toward four key questions for the future:

1. Directions: How can public policy be understood in terms of setting the direction and route of change; that is, shaping and creating markets rather than just fixing them? What can be learned from the ways in which directions were set in the past, and how can we stimulate more democratic debate about such directionality?

2. Evaluation: How can an alternative conceptualization of the role of the public sector in the economy (alternative to MFT) translate into new indicators and assessment tools for 
evaluating public policies, beyond the microeconomic cost/benefit analysis? How does this alter the crowding in/out narrative?

3. Organizational change: How should public organizations be structured so they accommodate the risk-taking and explorative capacity, and the capabilities needed to envision and manage contemporary challenges?

4. Risks and Rewards: How can this alternative conceptualization be put implemented so that it frames investment tools so that they not only socialize risk but also have the potential to socialize the rewards that enable "smart growth" to also be "inclusive growth"? 


\section{References}

Abraham, J. (2010). "Pharmaceuticalization of Society in Context: Theoretical, Empirical and Health Dimensions," Sociology, 44(4), 603-622.

Angell, M. (2004). The Truth about the Drug Companies. New York: Random House.

Arrow, K. (1951). "An Extension of the Basic Theorems of Classical Welfare Economics," Paper presented at the Second Berkeley Symposium on Mathematical Statistics and Probability, Berkeley.

Block, F. and Keller, M. (2011). State of Innovation: the U.S. Government's Role in Technology Development. Boulder: Paradigm.

Buchanan, J. (2003). "Public Choice: The Origins and Development of a Research Program," Champions of Freedom, 31.

Buck, T. (2013). "Brain Drain in Spain Leaves Scientific Research on the wane," Financial Times, June 13. Available at http://www.ft.com/intl/cms/s/0/adb56dfe-d40e-11e2-863900144feab7de.html (accessed 2/7/2014).

Buffett, W. (2011). "Stop Coddling the Super-Rich,” Available at http://www.nytimes.com/2011/08/15/opinion/stop-coddling-the-super-rich.html?_r=0 (accessed 14/7/2014).

Climate Policy Initiative. (2013). “The Global Landscape of Climate Finance 2013," CPI Report, October. Available at http://climatepolicyinitiative.org/wpcontent/uploads/2013/10/The-Global-Landscape-of-Climate-Finance-2013.pdf (accessed $1 / 6 / 2014)$.

Cohen, W.M., and Levinthal, D.A. (1990). "Absorptive Capacity: A New Perspective on Learning and Innovation," Administrative Science Quarterly, 35(1).

Dosi, G. (1982). "Technological Paradigms and Technological Trajectories: A Suggested Interpretation of the Determinants and Directions of Technical Change," Research Policy, 11(3), 147-162.

European Commission. (2010). "Europe 2020: A European Strategy for Smart, Sustainable and Inclusive Growth," Available at http://ec.europa.eu/eu2020/pdf/COMPLET\%20EN\%20BARROSO\%20\%20\%20007\%2 0-\%20Europe\%202020\%20-\%20EN\%20version.pdf (accessed 16/7/2014).

EuroWeek. (2011). "KfW Domination of ECP Ends Fears of SSA Crowding-out," EuroWeek, March 11. Available online at: http://www.globalcapital.com/article/k4qz6z833bhv/kfwdomination-of-ecp-ends-fears-of-ssa-crowding-out (accessed 2/7/2014). 
Falck, O., Gollier, C., and Woessmann, L. (2011). "Arguments for and against Policies to Promote National Champions,” In O. Falck, C. Gollier \& L. Woessmann (Eds.), Industrial Policy for National Champions (pp. 3-9). Cambridge, MA: MIT Press.

FMER (Federal Ministry of Education and Research), (2013). "Education and Research in Figures 2013," Available at http://www.bmbf.de/pub/education_and_research_in_figures_2013.pdf (accessed $16 / 7 / 2014)$.

Foray, D., Mowery, D., and Nelson, R.R. (2012). "Public R\&D and Social Challenges: What Lessons from Mission R\&D Programs?," Research Policy, 41(10), 1697-1902.

Fried, L., S. Shukla and S. Sawyer, eds. 2012. "Global Wind Report: Annual Market Update 2011," Global Wind Energy Council, March. Available at http://gwec. net/wpcontent/uploads/2012/06/Annual_report_2011_lowres.pdf (accessed 24/1/2013).

Friedman, B.M. (1979). "Crowding out or Crowding in? The Economic Consequences of Financing Government Deficits," Brookings Papers on Economic Activity, 3, 593-654.

Hanson, J.A. (2004). "Public Sector Banks and their Transformation," 6th Annual Financial Markets and Development Conference: The Role of State-Owned Financial Institutions Policy and Practice. Washington, D.C.: The Brookings Institution.

Hirschman, A.O. (1967). Development Projects Observed: Brookings Institution Press.

Judt, T. (2011). Ill Fares the Land. New York: Penguin Press.

Kakabadse, A., and Kakabadse, N. (2002). "Trends in Outsourcing:: Contrasting USA and Europe," European Management Journal, 20(2), 189-198.

Keynes, J.M. (1926). The End of Laissez-faire. London: Prometheus Books. . (2006 [1936]). General Theory of Employment, Interest and Money: Atlantic.

Krueger, A.O. (1974). "The Political Economy of the Rent-seeking Society," The American Economic Review, 64(3), 291-303.

LaMonica, M. (2013). "R\&D Faces its Own Fiscal Cliff," MIT Technology Review, February 28. Available at http://www.technologyreview.com/news/511886/rd-faces-its-ownfiscal-cliff/ (accessed 2/7/14).

Lazonick, W., and Mazzucato, M. 2013. "The Risk-Reward Nexus in the Innovation-Inequality Relationship: Who Takes the Risks? Who Gets the Rewards?," Industrial and Corporate Change, 22(4), 1093-1128.

Lisboa, M.B., and Latif, Z.A. (2013). “Democracy and Growth in Brazil,” Insper Working Paper, 311/2013. 
Mazzucato, M. (2013a). The Entrepreneurial State: Debunking the Public vs. Private Myth in Risk and Innovation. London: Anthem.

. (2013b). "Financing Innovation: Creative Destruction vs. Destructive Creation," Industrial and Corporate Change, 22(4), 851-867.

Mazzucato, M., and Penna, C. (2014). "Beyond Market Failures: The Role of State Investment Banks in the Economy," Paper presented at the Conference on Mission-Oriented Finance for Innovation, London.

Mazzucato, M., and Perez, C. (2014), "Innovation as Growth Policy," in The Triple Challenge: Europe in a New Age. J. Fagerberg, S. Laestadius, and B. Martin (eds.) Oxford University Press: Oxford, forthcoming.

Mowery, D.C. (2010). "Military R\&D and Innovation,” in B. H. Hall \& N. Rosenberg (Eds.), Handbook of the Economics of Innovation (Vol. 2, pp. 1219-1256).

National Research Council (2001). Energy Research at DOE: Was It Worth It? Energy Efficiency and Fossil Energy Research 1978 to 2000, Committee on Benefits of DOE R\&D on Energy Efficiency and Fossil Energy, Board on Energy and Environmental Systems, Division on Engineering and Physical Sciences. Available at http://www.nap.edu/catalog.php?record_id=10165 (accessed 22/4/2014).

Nelson, R.R., \& Winter, S.G. (1982). An Evolutionary Theory of Economic Change. Cambridge (MA): Belknap Press.

Perez, C. (2002). Technological Revolutions and Financial Capital: The Dynamics of Bubbles and Golden Ages. Cheltenham, UK: Edgar Elgar.

Polanyi, K. (2001 [1944]). The Great Transformation: The Political and Economic Origins of our Time. Boston: Beacon Press.

Rodrik, D. (2013). “Green Industrial Policy,” Princeton University Working Paper.

Schot, J., and Geels, F. (2007). "Typology of Sociotechnical Transition Pathways," Research Policy, 36 (3), 399-417.

Shellenberger, M., Nordhaus, T., Jenkins, J. and Trembath, A. (2012). "US Government Role in Shale Gas Fracking History: An Overview and Response to Our Critics," The Breakthrough, March 2. Available at http://thebreakthrough.org/archive/shale_gas_fracking_history_and (accessed 13/7/2014).

Stiglitz, J., \& Weiss, A. (1981). "Credit Rationing in Markets with Imperfect Information," American Economic Review, 3(71), 393-410. 
Stirling, A. (2009) "Direction, Distribution and Diversity! Pluralising Progress in Innovation, Sustainability and Development," STEPS Working Paper: Vol. 32.

. (2014). "Making Choices in the Face of Uncertainty," Themed Annual Report of the Government Chief Scientific Adviser, Chapter 2 (June). Draft mimeo.

The Economist. (2010). "Picking Winners, Saving Losers: The Global Revival of Industrial Policy," The Economist. Available online at: http://www.economist.com/node/16741043 (accessed 1/6/2014).

Tullock, G., Seldon, A., and Brady, G.L. (2002). “Government Failure: A Primer in Public Choice," Washington, DC: Cato Institute.

Weir, N. (2014). "Government R\&D Hit by Disproportionate Cuts, Again,” Campaign for Science and Engineering (CaSE), January 27. Available at http://sciencecampaign.org.uk/?p=13593 (accessed 23/5/2014).

Weiss, L. (2014). America Inc: Innovation and Enterprise in the National Security State. Cornell University Press, NY.

Wolf, C. (1988). Markets or Governments: Choosing Between Imperfect Alternatives. Cambridge, Mass.: MIT Press.

Wood, R. (2012). "Fallen Solyndra Won Bankruptcy Battle but Faces Tax War," Forbes, 11 June. Available at http://www.forbes.com/sites/robertwood/2012/11/06/fallen-solyndrawon-bankruptcy-battle-but-faces-tax-war/ (accessed 29/1/201 